University of Wollongong

Research Online

Faculty of Business - Papers (Archive)

Faculty of Business and Law

2013

Does political capital create value in the IPO market? Evidence from China

Qigui Liu

University of Wollongong, qigui@uow.edu.au

Jinghua Tang

University of Wollongong, jt163@uowmail.edu.au

Gary Gang Tian

University of Wollongong, gtian@uow.edu.au

Follow this and additional works at: https://ro.uow.edu.au/buspapers

Part of the Business Commons

Research Online is the open access institutional repository for the University of Wollongong. For further information contact the UOW Library: research-pubs@uow.edu.au 


\title{
Does political capital create value in the IPO market? Evidence from China
}

\begin{abstract}
This study examines the value of political capital in the Chinese IPO market. We find a positive relationship between a politically connected executive and the probability of IPO approval of entrepreneurial firms. We further identify that shareholders value those connections and give a market premium to connected firms after the firms go public. We provide evidence that other types of political capital gained through external sources, such as politically connected sponsors and PE investors, also bring benefits to the firms in their IPO approval, and these connections substitute for the effect of the executive's political connections on IPO approval. We argue that in emerging markets where government intervention is still prevalent, political capital does create value and entrepreneurial firms usually build political capital to facilitate their access to the IPO market, although other types of political capital do not bring further benefits into the post-IPO market.
\end{abstract}

\section{Keywords}

evidence, market, ipo, china, value, does, create, capital, political

Disciplines

Business

\section{Publication Details}

Liu, Q., Tang, J. \& Tian, G. (2013). Does political capital create value in the IPO market? Evidence from China. Journal of Corporate Finance, 23 (2013), 395-413. 
Does political capital create value in the IPO market? Evidence from China

Qigui Liu, Jinghua Tang, Gary Gang Tian*

School of Accounting\& Finance, University of Wollongong, Australia

\begin{abstract}
This study examines the value of political capital in the Chinese IPO market. We find a positive relationship between a politically connected executive and the probability of IPO approval of entrepreneurial firms. We further identify that shareholders value those connections and give a market premium to connected firms after the firms go public. We provide evidence that other types of political capital gained through external sources, such as politically connected sponsors and PE investors, also bring benefits to the firms in their IPO approval, and these connections substitute for the effect of the executive's political connections on IPO approval. We argue that in emerging markets where government intervention is still prevalent, political capital does create value and entrepreneurial firms usually build political capital to facilitate their access to the IPO market, although other types of political capital do not bring further benefits into the post-IPO market.
\end{abstract}

Key words: Political capital; IPO approval; Post-IPO performance; Emerging market

JEL Classification: G30, G38

\footnotetext{
*Corresponding author: E-mail: gtian@uow.edu.au, Ph: 61242214301.

Email addresses: qigui@uow.edu.au (Qigui Liu), jtang@uow.edu.au (Jinghua Tang), gtian@uow.edu.au (Gary Tian).
} 


\section{Introduction}

Previous studies have documented that political connections grease the wheels and are widespread around the world. Such connections are recognized as an important political capital that creates value for an individual company (Nee and Opper, 2013; Faccio, 2006). The literature shows that politically connected firms have better access to private financial markets than their non-connected counterparts, and thus, political connections are found to improve firm value and performance ${ }^{1}$, especially for firms not controlled by the state ${ }^{2}$. For example, politically connected firms have preferential access to bank loans and are more likely to obtain government bailouts with favorable regulatory conditions ${ }^{3}$. Moreover, minority shareholders are less likely to expect regulators to enforce new regulations and rules on connected firms, although these connected firms are found to have poor quality accounting information ${ }^{4}$.

Given the importance of political capital around the world, it is not surprising that its value is even more significant in emerging markets, where the quality of government is still low and government intervention remains prevalent. Empirical evidence does indicate that in those markets, firms usually have a strong incentive to obtain political capital by building political connections to access external financial resources, i.e., to seek rent from the government (so-called rent-seeking) (Fisman, 2001; Fan et al., 2011).

However, previous studies have focused mainly on the value of political connections in a firm's access to private financial markets or directly linked firms' political connections to firm value. Although a few recent studies have investigated the effect of political connections on post-IPO performance ${ }^{5}$, the value of political capital in the process of firms going public, particularly whether political capital creates value in the form of probability of IPO approval, has never been investigated. More importantly, most previous studies use politically connected executives as a proxy for political capital, whereas other types of political capital, such as a politically connected sponsor/underwriter (sponsor) ${ }^{6}$ or the presence of private equity and venture capital $(\mathrm{PE})^{7}$, are ignored. This study attempts to fill these gaps by investigating the value of political capital when accessing the IPO market by using a much broader definition of political capital. We identify political capital as not only the executive's political connections but also the political connections of sponsors and the presence of PE. In addition to the natural experiment and Heckman two-step regression that we apply to address the issue of endogeneity, we also select the founding executive's connections as 'born' political connections for a robustness check. On this basis, our results greatly alleviate the issues of endogeneity.

To conduct our study, we first need an environment in which the value of political capital for accessing the IPO market can be clearly identified and measured. Second, the institutional environment should allow state-controlled firms and entrepreneurial firms ${ }^{8}$ to co-exist; in China, entrepreneurial firms are still

\footnotetext{
1 See, for example, Roberts, 1990; Fisman, 2001; Johnson and Mitton, 2003; Ramalho, 2007; Li et al., 2008 ; Chen et al., 2011.

2 See Li et al., 2008.

3 See, for examples, Khwaja and Mian, 2005; Adhikari et al., 2006; Agrawal and Knoeber, 2001; Claessens et al., 2008; Faccio, 2006; Faccio et al., 2006; and Li et al., 2008.

4 See Chaney et al., 2011; and Berkman et al., 2010.

${ }^{5}$ For example, Fan et al. (2007) examine the effect of political connections on the post-IPO performance of Chinese state-controlled firms; their study ignores the effect of political connections on firms' accessing the IPO market and focuses mainly on political connections in state-controlled firms, within which the effect of political connections can be diluted by state ownership. Liu et al. (2012) and Wu et al. (2012) find that politically connected IPOs outperform non-connected IPOs in the long term, using a pooled sample of Chinese firms that includes both state-controlled and non-state-controlled firms.

${ }^{6}$ A sponsor, taking responsibility for his endorsement of an IPO by improving the quality of listed companies' prospectus disclosures, is also a primary underwriter in the Chinese IPO market. This study uses sponsor to represent both sponsors and underwriters.

${ }^{7} \mathrm{PE}$ and VC investors are referred to as PE in this paper because, as indicated by Bruton et al. (2002) and Naqi and Hettihewa (2007), VC investors in the context of emerging markets are actually PE, in contrast to this term's meaning in the US market. This paper uses a dummy PE as a proxy for both PE- and VC-backed IPOs.

${ }^{8}$ In this study, we divide Chinese firms into state-controlled firms and entrepreneurial firms, according to their controlling shareholders. State-controlled firms have the state or other government representative entities as controlling shareholders; entrepreneurial firms are ultimately controlled by a founding family or an individual entrepreneur. Our study mainly focuses on entrepreneurial firms.
} 
discriminated against in accessing financial sources, so they have a strong incentive to seek benefits from political capital. Lastly, government intervention in the economy under examination should be prevalent, and the economy should be dominated by networking and relationships rather than a complete and well-developed legal system so that the value of political capital is more evident.

The emerging capital market in China provides an ideal institutional environment to conduct our research for several reasons. First, the IPO process in the Chinese capital market is still regulated: companies cannot issue new shares in the capital market until that application has been approved by the China Securities Regulatory Commission (CSRC), an authority of the Chinese government. Given that the government's IPO screening process is still essential for prospective IPO firms, political capital is important for getting firms' IPO application approved because they enable connected firms not only to communicate more effectively with the regulators but to obtain more government support for their business operations. Therefore, the strictly regulated IPO market in China provides a direct measurement of the value of political capital in the IPO market ${ }^{9}$.

Another distinct feature of the Chinese capital market, which differs from other emerging markets, is the continuing rule of the Communist Party and ongoing ideological discrimination against entrepreneurial ownership, despite a substantial reform of the economy ( $\mathrm{Li}$ et al., 2006; Li et al., 2008). Previous literature suggests that Chinese entrepreneurial firms are discriminated against for accessing bank loans (Cull and Xu, 2003; Li et al., 2009; Firth et al., 2009). This discrimination is why Chinese entrepreneurial firms tend to establish and maintain a close relationship with the government through a politically connected executive- to mitigate ideological discrimination and gain better access to external financial resources (Li et al., 2008). Given that state-controlled firms already have a closer link with the government through government ownership and control, the role of political connections in state-controlled firms could be diluted. Furthermore, the value-creating effect of political connections in state-controlled firms is also offset by the value-destroying effect derived from multiple goals in these firms. That is, although political connections exist in both entrepreneurial and state-controlled firms, these political connections become political capital, with its value-creating effect, only in entrepreneurial firms. Therefore, this study mainly focuses on political connections in entrepreneurial firms, but for completeness and to ensure the robustness of our results, we also examine the effect of a politically connected executive on IPO approval in state-controlled firms. Our results confirm that the role of the politically connected executive is insignificant in state-controlled firms.

Lastly, the value of political capital is expected to be more pronounced in the Chinese market than in other markets because the business environment in China is dominated by relationships and networks rather than a formal legal system; in such situations, people are usually unwilling to enter into formal contracts, and any contracts tend to be poorly drafted. Under these circumstances, prospective Chinese entrepreneurial firms have strong incentives to establish political capital through every available channel, and such political capital could create value in the IPO market.

In addition to political connections created by their executive (widely documented in previous studies), other important channels through which prospective IPO firms seek rent via political connections are brought in from external sources to help them access the IPO market. The first intuitive way is to seek politically connected sponsors. Previous studies have indicated that politically connected sponsors in China do influence regulators' decisions (Chen et al., 2011). The other way is to seek PE investors and use their established connections. Our data indicate that the majority of PE firms in China are either state-controlled, with natural connections with governments, or have an executive with strong personal connections with top government officials ${ }^{10}$; in both cases, the firms can exert a significant amount of influence on the IPO regulators. Therefore, we expect that the politically connected sponsor and PE in

\footnotetext{
${ }^{9}$ Although there are also IPO regulations in developed markets, it is difficult to measure the value of political capital because the markets are not highly regulated by the government.

${ }^{10}$ For example, Wen Yunsong, the son of the former prime minister of China, was the former CEO and an important partner of new Horizon Capital, one of the best known PE investors in China.
} 
China provide another channel for forging political connections, which increases the probability of firms' IPO approval.

However, political connections through external sources may not necessarily result in a better post-IPO performance by implementing active monitoring on prospective IPO firms. The existing CSRC regulation requires that the sponsor be responsible to the issuer for up to two years after the IPO ${ }^{11}$, which may increase the sponsors' incentive to monitor IPO firms during the post-IPO period. However, we are concerned about the effect of the political connections of sponsors on post-IPO performance. It is not clear whether politically connected sponsors are more responsible to the issuer's post-IPO performance than those without political connections. As far as PE is concerned, conventional wisdom indicates that PE investors in the US select, monitor and exit firms to make a profit. Thus, they play an important monitoring role in the firms in which they invest due to their concern for their own reputation (Gompers, 1995; Engel et al., 2002; Hochberg, 2008). Recently, Krishnan, Ivanov, Masulis and Singh (2011) find that having reputable PEs plays an active monitoring role in the post-IPO period, resulting in better post-IPO performance than that of other IPOs in the US market. However, in contrast to developed countries, the monitoring role of PE in China is expected to be impaired because PE investors normally hold only a small portion of shares compared to the powerful controlling shareholders. Moreover, they invest in a prospective IPO firm shortly before the IPO application and exit shortly after the lock-up period $^{12}$; therefore, they do not care much about their reputation. Overall, the existing literature focuses on the reputation of PE and finds that reputable PE outperform other PE-backed IPOs, whereas our paper examines the effect of the presence of PE rather than PE reputation on post-IPO performance. Therefore, we expect that a politically connected sponsor and the presence of $\mathrm{PE}$ do not have a positive effect on firms' post-IPO performance in the Chinese IPO market.

Using a recent sample of Chinese IPO cases from 2004 to $2010^{13}$, we conduct a series of empirical analyses to provide evidence for our hypotheses. Our findings confirm that there is a positive relationship between executives' political connections and the probability of an IPO application being approved in entrepreneurial firms, and as expected, this positive relationship does not exist in state-controlled firms. Furthermore, we extend our research to the effect of politically connected executives on the post-IPO performance of entrepreneurial firms, and our results confirm that minority shareholders do value executive connection as political capital and give a market premium to connected firms after IPO.

Our results provide further evidence that other types of connections through politically connected sponsors and PE investors also have a positive effect on the IPO approval of entrepreneurial firms. We further find that the other types of connections substitute for the effect of the executive's political connections on IPO approval. Nevertheless, shareholders do not value these types of political capital in the post-IPO market. These results indicate that besides politically connected executives, Chinese entrepreneurial firms also seek other types of political capital to help secure approval for their IPO application. However, the value of other forms of political capital only seems to exist in the IPO-approval market rather than the post-IPO market.

There could be some concern that our results may be influenced by potential endogeneity problems, which means that both IPO approval and political connections are dominated by unobserved phenomena. To eliminate any potential endogeneity, we conduct three tests. First, we re-conduct our regressions using a natural experimental method, which means that we investigate whether the positive effect of political capital on IPO approval was weakened after the government reduced its intervention in the IPO

\footnotetext{
${ }^{11}$ Initially in 2004, CSRC announced a regulation to punish sponsors if sponsored firms' accounting performance deteriorated significantly during the first year of their listing. Then, in 2009, CSRC issued a new regulation to extend the post-IPO years for a sponsor's responsibility to two years for firms listed in the main board and three years for firms listed in the Growth Enterprise Market (GEM) board. According to these measures, if operating profits drop by more than $50 \%$, the CSRC may reject any new applications sponsored by the sponsor (CSRC [2009], Decree No.63).

12 Our statistics show that approximately $70 \%$ of PE investment in prospective firms is made within two years before the IPO application, and more than $80 \%$ of PE investors exit or reduce their holding within one year after the lock-up period.

${ }_{13}$ Our IPO sample is from the period 2004 to 2010, but because firms rejected for IPO did not disclose their prospectus and financial data until 2006, our regression analysis only includes the sample from the period 2006 to 2010.
} 
regulatory market. Second, we re-conduct all our regressions using a Heckman two-step regression with an instrumental variable approach. We lastly re-conduct our regression regarding the effect of politically connected executives on IPO approval using 'born' political connections (defined as the founders' connections when the firm was established) as new measures of political connections. We find that our main results are robust after the endogeneity problem is addressed by these analyses.

Our study contributes to the current literature by examining the effect of political connections on firms' accessing the equity market, something that has received scant attention in previous literature. For the first time, we empirically document that the IPO applications of firms with political capital are more likely to be approved by regulators, which means that political capital also facilitates access to the IPO market. Previous studies have shown that connected firms have easier access to bank loans (e.g., Khwaja and Mian, 2005; Faccio, 2006; Faccio et al., 2006; Claessens et al., 2008). We complement these studies by showing that connected firms are also better able to access funds in the public equity market.

Second, conventional studies on the consequences of political capital mainly focus on executives' connections (Faccio et al., 2006; Fan et al., 2007; Claessens et al., 2008); we extend our definition of political capital to include other types of political connections and find that all politically connected sponsors and the presence of PE have positive impacts on IPO approval. Therefore, this study extends our understanding of the role of sponsors and PE in an emerging market. From the perspective of investment banks, Chen et al. (2011) find that a politically connected underwriter can increase the likelihood that their clients' IPO applications are approved. This study differs from their paper because from a firm's perspective, we regard a politically connected sponsor only as part of a firm's political capital. Therefore, in addition to the effect of a politically connected sponsor on IPO approval and post-IPO performance, we also investigate whether a politically connected sponsor, as one type of political capital, has a substitutionary or complementary effect on IPO approval with the politically connected executive. In addition, Chen et al. (2011) examine the effect of sponsors' political connections on IPO approval in a pooled sample of all listed firms without distinguishing between state-controlled and entrepreneurial firms. We previously argue that political connections become political capital, with its value-creating effect, only in entrepreneurial firms. By focusing on entrepreneurial firms, our study provides fresh evidence that in an economy with a weak legal system where entrepreneurial firms are discriminated against, entrepreneurial firms have an incentive to seek politically connected sponsors as well as PE to tap into the IPO market. Therefore, this study provides much more robust and comprehensive evidence of the effect of politically connected sponsors on IPO approval.

Lastly, prior studies show that political capital (measured by politically connected executives) destroys value in state-controlled firms by decreasing post-IPO performance (Fan et al., 2007) or creates value in a pooled sample of all listed firms without distinguishing between state-controlled and entrepreneurial firms (Liu et al., 2012; Wu et al., 2012). Our study extends this literature by confirming the value-creating effect of executives' political connections in a sample of entrepreneurial firms. More importantly, we further document that other types of political capital create value in IPO approval but have no impact on post-IPO performance in these firms.

The remainder of this study is organized as follows: Section 2 describes the institutional background of the IPO market in China. Section 3 describes this study's sample selection, variable construction and summary statistics. Section 4 presents the results of our main empirical and robustness tests. Section 5 concludes the paper.

\section{Institutional environment and development of hypotheses}

\subsection{Institutional environment}

\subsubsection{Development of the IPO market in China}

The Chinese government established its capital market in the early 1990s, and since this time, its IPO market has developed in three stages. In the first stage, the IPO market was dominated by the central government until 1999, when the Security Law was implemented, and a quota system was used by 
regulators; i.e., the IPO market was directly guided by the CSRC. Under the quota system, the overall size of the IPO market was determined on a yearly basis by the central government, and each province received its IPO quota from the CSRC and identified prospective candidates based on applications by firms under its jurisdiction. However, these candidates still needed to obtain approval from the regional security regulator, the stock exchange and the CSRC to complete the IPO process (Chen, Guan, Zhang, and Zhao, 2011). Because the aim of the Chinese capital market at this stage was to serve the reforms of state-controlled firms, these firms usually received priority for an IPO, whereas only a few entrepreneurial firms would be selected for listing in the markets.

Under the channel system adopted in 2000, regulators assigned channels directly to sponsors, according to their size and performance. Sponsors with channels recommended prospective firms to the CSRC for an IPO. CSRC officials initially evaluated the IPO applications, and the examination committee of the CSRC eventually approved the decision. Although the channel system was more market-oriented than the quota system, it still had limitations because it constrained competition between the sponsors. This system was thus abandoned in early 2004 in favor of a sponsorship system in which the sponsor recommends its client firms for an IPO listing, which must then be approved by the CSRC, and only those who pass the CSRC evaluation and approval can apply for an IPO. This system makes the regulation of IPO much more market-oriented than the channel system because it gives sponsors more incentive to deliver a diligent service in the IPO market and monitor their clients more intensively (Chen et al., 2011). This system encourages the development of a Chinese IPO market; for instance, listed firms in China grew from 1,300 in 2004 to 2,400 by the end of 2011. However, because the government still intervenes in firms' access to the IPO market via eventual approval from the CSRC, even under the sponsorship system, it is essential to examine whether connected firms have any priority in accessing the IPO market.

Another important consequence of the sponsorship system is that a large number of entrepreneurial firms have the opportunity to go public; for instance, our sample shows that more than $80 \%$ of all successful IPO cases from 2004 to 2010 were entrepreneurial firms. The blooming of entrepreneurial firms in the Chinese capital market also promotes the emergence and development of PE investors, who are playing an increasingly important role in the process of firms' IPO. However, unlike their counterparts in the US, PE investors in China usually invest in a pre-IPO firm shortly before they complete an IPO application and with an entrance price that is lower than the issue price for their IPO. However, why are PE investors able to invest in the firms with relatively low prices? One reason may be that PE investors in China usually have strong political connections that can help firms gain IPO approval because PE investors naturally have strong connections with political leaders. Therefore, entrepreneurial firms have an incentive to seek PE investors who will use their political connections to enter the IPO market by providing lower entrance prices for PE investment.

\subsubsection{IPO screening process and regulation in China}

As discussed above, even under the sponsorship system, all IPOs in China must be approved by the CSRC. Usually, an IPO application submitted to the CSRC is first examined by their officials, and if it meets basic legislative requirements, it is then passed to the Stock Issuance Examination and Verification Committee (SIEVC) for further examination and verification (Yang, 2013).

The Chinese government has promulgated a number of laws and regulations to guide the selection of an IPO. In addition to clearly outlined rules such as the minimum requirements for the value of net assets and operational history, this legislation also contains large amounts of soft, qualitative and ambiguous criteria. CSRC [2006] Decree No. 30, for example, requires that "an issuer shall not have any major debt-paying risk or be involved with any major contingent issue such as guaranty, litigation and arbitration that may negatively affect its business operations" and that "an issuer shall not be under any circumstances where its capability of making profits continuously is materially affected". One circumstance listed in the regulation states that the issuer's "industrial status or business environment has greatly changed or will greatly change". Another example of this ambiguity is the statement that "the amount of raised funds shall be commensurate to an issuer's present business scale, financial status, technical level and management capability”. The purpose of these qualitative provisions is to give CSRC 
officials and members of SIEVC the flexibility to select better-performing firms with a potential for growth. However, these ambiguous requirements also give CSRC officials and SIEVC members a great amount of discretion in making decisions that create room for political connections to play a role in the IPO screening process (Yang, 2013).

Under these circumstances prospective IPO companies usually have a strong incentive to seek rent from the government through political connections to have their IPO applications approved. For instance, according to a recent report that demonstrates the importance of political connections to the regulatory authority in the IPO screening process, prospective IPO companies often set up offices in Beijing, where the CSRC is located, solely to support their IPO plans. The main purpose of these offices is to enable company representatives to build connections with officials who are familiar with the regulatory process and can determine the fate of their IPO applications. Prospective IPO companies may seek advice from officials on how to solve complicated issues while preparing their IPOs for application, receive timely feedback about the status of their applications and even influence the voting outcome through their connections with the officials (Yang, 2013).

Overall, the Chinese government still intervenes in the IPO market, even as it has become more market-oriented. Prospective IPO firms, especially entrepreneurial firms, which are still ideologically discriminated against by large state-owned banks, have limited access to bank loans (Li et al., 2006; Li et al., 2008); such constraints give them a strong incentive to seek rent through political connections to get their IPO application approved so they can access the public equity market in raising their capital.

\subsection{Development of the hypotheses}

\subsubsection{The effect of executive's politically connections on IPO approval and post-IPO performance}

We expect that executives' political connections may have a positive impact on the probability of IPO approval because in transition economies characterized by a large number of governmental interventions and discrimination of entrepreneurial firms, political capital can usually bring benefits to the connected firms; thus, rent-seeking activities through political capital are usually quite prevalent. Previous studies have shown that as a major type of political capital, executive political connections do create value in the private financing market by helping firms gain access bank loans. Therefore, we expect that executives' political connections also help firms access the IPO market because the requirements for IPO listing in China are quite ambiguous and create room for political connections to play a role. Under these circumstances, most prospective firms usually try to communicate more effectively with the regulators and obtain more government support through a politically connected executive ${ }^{14}$. We thus develop the following hypothesis to provide empirical evidence for our expectation:

H1: Executives' political connections are positively related to the probability of IPO approval of entrepreneurial firms.

In addition, given that entrepreneurial firms with political connections are more likely to obtain resources and support from the government, minority shareholders in the secondary market may expect that politically connected executives will continue to bring benefits to the firms after IPO; thus, they will give a market premium to those firms with politically connected executives. As a result, those connected

\footnotetext{
${ }^{14}$ We include both CEOs' and chairmen's political connections as executives' political connections because both are important in Chinese firms. According to Chinese company law, a general manager is regarded as the equivalent of a CEO in the United States (Fan et al., 2007). However, the chairman of the board is actually also a full-time executive position, a situation that may differ from that in other countries, and ranks higher than the general manager (Firth et al., 2006). In Chinese firms, the chairman chairs the board of directors, deals with external parties, is involved with internal decision making and is the legal representative of the company. Chairmen are involved in the day-to-day management of the business and have overall responsibility for operations (Li and Yang, 2003). In most cases, the ultimate controlling shareholder effectively controls the company through the nomination of the chairman of the board. The top two executives in Chinese firms, the general manager and chairman of the board, are usually regarded as the CEO in previous literature concerning the US context.
} 
firms will outperform their non-connected counterparts after the firms go public. Therefore, we further develop the following hypothesis regarding the effect of political connections on post-IPO performance:

H2: Politically connected executives are positively associated with post-IPO performance of entrepreneurial firms.

\subsubsection{The effect of other political capital on IPO approval}

As discussed above, besides executive political connection, entrepreneurial firms in China will also seek political capital through external sources, including political connections by sponsors and PE investors who will also bring benefits to entrepreneurial firms through their networking and relationships with the government. Chinese pre-IPO firms provide a unique setting to examine whether these connections bring benefits other than monitoring to entrepreneurial firms. We expect that Chinese entrepreneurial firms have strong incentives to seek politically connected sponsors and PE investors because both provide strong political connections, which helps firms access the IPO market. Thus, we establish the following hypothesis:

H3a: Politically connected sponsors and the presence of PE investors are positively associated with firms' IPO approval.

If, as expected, politically connected sponsors and the presence of PE investors provide additional channels that entrepreneurial firms can use to help their IPO application be approved, the question is whether they play a different role with politically connected executives in the IPO approval market. We expect that firms' first priority is to seek politically connected executives because they are internal political capital and may bring resources in many ways, not only in the IPO approval market. However, due to the scarcity of talented executives with political connections, not every firm is able to seek politically connected executives; such firms are more likely to seek politically connected sponsors or PE. Therefore, the effect of politically connected sponsors and PE on IPO approval is expected to be stronger in firms without politically connected executives, which means that their effect on IPO approval is a substitute for executives' connection. We therefore develop the following hypothesis:

H3b: The positive effect of politically connected sponsors and PE is more pronounced in firms without a politically connected executive.

\section{Data, variables and summary statistics}

\subsection{Data collection}

This study focuses on cases of IPO applications screened by the CSRC between January 1, 2004 and December 31, 2010. We manually collect information on the IPO applications from the CSRC website, whereas the regulatory decision on IPO applications is compiled from announcements publicly available on the CSRC website. Information on firms' political connections is also collected manually from firms' prospectus, disclosed either by firms who applied previously or by their sponsors. Post-IPO performance information is collected from the CSMAR dataset of the China Stock Market Trading Database (2004-2010), whereas pre-IPO financial information about firms with IPO applications is collected either from the IPO research database of Chinese firms (2004-2010) provided by the CSMAR dataset or manually from firms' prospectuses ${ }^{15}$. We drop all IPO application cases from the financial industry (there are 19 such cases in the sample, including commercial banks, insurance companies and investment banks) when conducting our empirical tests because such applications have an approval rate of $100 \%$. Next, we

\footnotetext{
${ }^{15}$ Because the IPO research database of Chinese firms only includes pre-IPO and financial information of successful IPO firms, we manually collect the information about unsuccessful IPO firms.
} 
drop 171 IPO applications from state-controlled firms. The resulting sample consists of 806 IPO applications from entrepreneurial firms for the period between 2004 and $2010^{16}$. In our regression analysis, we further exclude IPO applications for the period between 2004 and 2005 because the financial data of the rejected cases are not disclosed and thus cannot be obtained (55 cases are dropped, leaving a sample of 751 cases). We lastly drop two cases because their relevant information cannot be acquired, leaving a sample of 749 cases for regression.

\subsection{Variable definition}

IPO approval is defined as a dummy variable APPROVAL that equals 1 if the firm's IPO application is approved by the CSRC and 0 otherwise.

This study calculates both the cumulative abnormal market-adjusted stock returns (CARs) and the buy-and-hold market-adjusted stock returns (BAHRs) to measure post-IPO performance. We use 3-, 6and 12-month post-IPO performance to measure short-term performance and 24- and 36-month post-IPO performance to measure long-term performance.

The key independent variable used in this study is firms' political capital. We create four variables to measure political capital. First, following Fan et al. (2007), we define a firm as having a politically connected executive (PCCEO) as a dummy variable that equals 1 if either the CEO or chairman of the board currently serves or formerly served in the government, or as a deputy of the People's Congress, or the People's Political Consultative Conference. A politically connected sponsor is similarly defined, and the dummy variable PCSPON equals 1 if the firm's sponsor is politically connected. Lastly, the dummy variable PE equals 1 if the firm has at least one PE investor when the IPO application is submitted.

To conduct our regression analysis, we also include several control variables in our regression models to control for other factors that may have an impact on the probability of IPO approval. Detailed definitions of all variables are reported in Appendix A.

\subsection{Descriptive analysis and univariate test}

\subsubsection{Distribution of the sample and summary statistics}

Table 1 presents the distribution of the sample and the summary statistics of our sample. Panel A presents the distribution of IPO approval based on industry. The panel shows that IPO applications from the public utilities and real estate industry have the lowest approval rate. Panels $\mathrm{B}$ and $\mathrm{C}$ provide the distribution of IPO approval based on year and listed board ${ }^{17}$, which demonstrate that the IPO approval rates according to year and board do not fluctuate very much.

The summary statistics of our main variables are reported in panel $\mathrm{D}$, where the average approval rate of IPO applications is shown to be 0.83 , indicating that approximately $83 \%$ of total IPO applications were approved by regulators during our research period. In addition, $44 \%$ of our sample firms have a politically connected executive, whereas $50 \%$ and $56 \%$ of our sample firms have politically connected sponsors and PE investors, respectively.

For the main control variables, we show that the mean and median of firm size are 506 and 301 million, respectively. The average leverage ratio, ROE and current ratio are approximately 52.05\%, $28.83 \%$ and $1.74 \%$, respectively. In addition, we find that the average earnings management and operational risks are 0.11 and 0.91 , respectively, whereas approximately $4 \%$ of Chinese entrepreneurial firms have sponsors with a good reputation. State ownership in these entrepreneurial firms is rare, with approximately $1.86 \%$ of the total shares being state-owned.

\footnotetext{
${ }^{16}$ We begin our research period in 2004 because (1) the Chinese CSRC did not disclose its decision about whether an IPO application was approved or rejected until 2004; and (2) the sponsorship system in the Chinese IPO market was implemented after 2004. Thus, our period covers all IPO applications under the sponsorship system.

17 There are three listed boards in the Chinese capital market: the main board in the Shanghai/Shenzhen Stock Exchange; the Small and Medium-sized Enterprises Board in the Shenzhen Stock Exchange; and the Growth Enterprises Market Board in the Shenzhen Stock Exchange.
} 
Table 1

Sample distribution and summary statistics: Full sample.

Panel A. Distribution of IPO approval based on industry. Classification of industry is based on Fan, Wong and Zhang (2007).

\begin{tabular}{lrrrr} 
Industry & Obs. & Percentage & Number of IPO approvals & Probability of IPO approval \\
Public utilities & 57 & $7.59 \%$ & 31 & $54.39 \%$ \\
Real estate & 6 & $0.80 \%$ & 4 & $66.67 \%$ \\
Conglomerate & 108 & $14.38 \%$ & 106 & $98.15 \%$ \\
Industrial & 559 & $74.43 \%$ & 462 & $82.65 \%$ \\
Commercial & 21 & $2.80 \%$ & 20 & $95.24 \%$ \\
Total & 751 & $100.00 \%$ & 623 & $82.96 \%$ \\
\hline
\end{tabular}

Panel B. Distribution of IPO approval based on year.

\begin{tabular}{lrrrr} 
Year & Obs. & Percentage & Number of IPO approvals & Probability of IPO approval \\
2006 & 43 & 5.73 & 34 & 79.07 \\
2007 & 100 & 13.32 & 73 & 73.00 \\
2008 & 88 & 11.72 & 73 & 82.95 \\
2009 & 161 & 21.44 & 138 & 85.71 \\
2010 & 359 & 47.80 & 305 & 84.96 \\
Total & 751 & $100.00 \%$ & 623 & $82.96 \%$ \\
\hline
\end{tabular}

Panel C. Distribution of IPO approval based on listed board.

\begin{tabular}{lrrrr}
\hline Board & Obs. & Percentage & Number of IPO approvals & Probability of IPO approval \\
Main board & 24 & 3.20 & 17 & 70.83 \\
SME board & 503 & 66.98 & 414 & 82.31 \\
GEM board & 224 & 29.83 & 192 & 85.71 \\
Total & 751 & $100.00 \%$ & 623 & $82.96 \%$ \\
\hline
\end{tabular}

Panel D. Summary statistics. This panel presents the mean, median, maximum, minimum and standard deviation for major variables used in the paper. Definitions of variables are reported in Appendix A.

\begin{tabular}{|c|c|c|c|c|c|c|}
\hline Variable & Obs & Mean & Median & Std. Dev. & Min & Max \\
\hline APPROVAL & 751 & 0.83 & 1.00 & 0.38 & 0.00 & 1.00 \\
\hline PCCEO & 751 & 0.44 & 0.00 & 0.50 & 0.00 & 1.00 \\
\hline PCSPON & 751 & 0.50 & 1.00 & 0.50 & 0.00 & 1.00 \\
\hline PE & 751 & 0.56 & 1.00 & 0.50 & 0.00 & 1.00 \\
\hline SIZE (100 Million RMB) & 749 & 5.06 & 3.01 & 7.49 & 0.36 & 19.38 \\
\hline LEVERAGE (\%) & 749 & 52.05 & 53.22 & 16.59 & 5.87 & 217.20 \\
\hline ROE (\%) & 749 & 28.83 & 27.24 & 10.51 & 4.10 & 92.20 \\
\hline CURRENT & 749 & 1.74 & 1.42 & 1.20 & 0.44 & 14.34 \\
\hline EM & 749 & 0.11 & 0.06 & 0.54 & 0.00 & 14.38 \\
\hline OP-RISK & 749 & 0.91 & 0.34 & 3.12 & 0.00 & 66.44 \\
\hline TOP5 & 751 & 0.04 & 0.00 & 0.19 & 0.00 & 1.00 \\
\hline PSTATE(\%) & 751 & 1.86 & 0.00 & 6.02 & 0.00 & 41.74 \\
\hline
\end{tabular}

\subsubsection{Univariate test}

The results of the univariate test of our sample are reported in Table 2, where panels A and B present the results of IPO approval and post-IPO performance of firms with and without a politically connected 
executive $^{18}$, whereas panels $\mathrm{C}$ and D present the univariate tests of IPO approval and post-IPO performance of firms with and without other political capital. To be consistent with the regression results, all of these tests are based on a sample that exclude the period between 2004 and 2005. We then provide a univariate test in panel $\mathrm{E}$ to show whether politically connected executives create value during the period between 2004 and 2005 only.

As shown in panel A, firms with a politically connected executive have a statistically significantly higher rate of IPO approval than their non-connected counterparts, which confirms our hypothesis H1. As expected, there is no significant difference between firms with and without a politically connected executive in state-controlled firms. The results in panel B indicate that firms with politically connected executives outperform firms without in terms of post-IPO performance, and the differences are significant both statistically and economically. Thus, our hypothesis $\mathrm{H} 2$ is also confirmed.

We show in panel $\mathrm{C}$ that firms with politically connected sponsors and PE investors have a significantly higher IPO approval rate than those without such connections, which is consistent with our hypothesis H3. We also conduct a univariate test of firms with and without other political capital, but only some of the results are reported in panel $\mathrm{D}$ to save space. As shown in panel $\mathrm{D}$, we find there is no significant difference between firms with and without politically connected sponsors, indicating that other political capital does not create value in a post-IPO market.

The results in panel E show that in the period spanning from 2004 to 2005, the IPO approval rate of firms with politically connected executives is $85.29 \%$, whereas that of firms without connected executives is only $52.17 \%$. The difference of $33.12 \%$, which is more than three times the difference between 2006 and 2010 (9.24\%), is statistically significant. The results indicate that the value of political capital is more pronounced over the period from 2004 to 2005; thus, although we exclude 2004 and 2005 in our analysis due to a lack of financial data, our results would be even more robust if our analysis covered the period from 2004 to 2010.

Table 2

Univariate Test.

Panel A. IPO approval of firms with and without politically connected executives: entrepreneur firms and state-controlled firms. PCCEO and NPCCEO represent firms with and without politically connected executives. *** indicates significance at the $1 \%$ level.

\begin{tabular}{clrrrc}
\hline & & Obs. & Mean (\%) & Diff (\%) & P-value \\
\hline \multirow{2}{*}{ Sample of entrepreneur firms } & NPCCEO & 422 & 78.91 & & \\
& PCCEO & 329 & 88.15 & 9.24 & $0.00^{* * *}$ \\
\multirow{2}{*}{ Sample of state-controlled firms } & NPCCEO & 67 & 82.09 & 2.38 & 0.68 \\
& PCCEO & 103 & 84.46 & & \\
\hline
\end{tabular}

Panel B. Post-IPO performance of firms with and without politically connected executives. PCCEO and NPCCEO represent firms with and without politically connected executives. CAR3, CAR6, CAR12, CAR24 and CAR36 represent the cumulative abnormal returns for 3, 6, 12, 23 and 36 months after IPO, respectively. BAHR3, BAHR6, BAHR12, BAHR24 and BAHR36 represent the buy and hold returns for $3,6,12,23$ and 36 months after IPO, respectively. ***, ** and * indicate significance at the $1 \%, 5 \%$ and $10 \%$ levels, respectively.

\begin{tabular}{lrrrrr}
\hline & CAR3 (\%) & CAR6 (\%) & CAR12 (\%) & CAR24 (\%) & CAR36 (\%) \\
NPCCEO & Mean & Mean & Mean & Mean & Mean \\
PCCEO & -5.10 & -4.12 & -4.99 & 0.15 & 20.36 \\
Diff. & -3.10 & -1.34 & -2.15 & 6.24 & 36.25 \\
& $2.00^{*}$ & $2.78^{*}$ & 2.84 & $6.09^{* *}$ & $15.89 * *$ \\
& BAHR3 (\%) & BAHR6 (\%) & BAHR12 (\%) & BAHR24 (\%) & BAHR36 (\%) \\
\hline
\end{tabular}

\footnotetext{
${ }^{18}$ Our research mainly focuses on entrepreneurial firms; however, for completeness, we also present the results of a univariate test of IPO approval of state-controlled firms with and without politically connected executives.
} 


\begin{tabular}{|c|c|c|c|c|c|}
\hline & Mean & Mean & Mean & Mean & Mean \\
\hline NPCCEO & -5.30 & -5.95 & -9.16 & 0.39 & 11.64 \\
\hline PCCEO & -3.50 & -2.81 & -6.18 & 5.42 & 31.36 \\
\hline Diff. & $1.80 *$ & $3.14 *$ & 2.98 & 5.03* & $19.72 * *$ \\
\hline
\end{tabular}

Panel C. IPO approval of firms with and without connected sponsors and PE investors. PCSPON and NPCSPON represent firms with and without politically connected sponsors. PE and NPE refer to firms with and without PE investors. ** and *** indicate significance at the $10 \%$ and $5 \%$ levels, respectively.

\begin{tabular}{llrrrc}
\hline & & Obs. & Mean (\%) & Diff (\%) & P-value \\
Sample of entrepreneurial & NPCSPON & 375 & 80.97 & \multirow{2}{*}{4.84} & $0.08^{*}$ \\
\cline { 2 - 4 } firms & PCSPON & 376 & 84.92 & & \\
& NPE & 329 & 79.03 & \multirow{2}{*}{6.99} & $0.01^{* * *}$ \\
\hline
\end{tabular}

Panel D. Post-IPO performance of firms with and without other political capital. PCSPON and NPCSPON refer to firms with and without politically connected sponsors. CAR3, CAR6, CAR12, CAR24 and CAR36 represent the cumulative abnormal returns for 3, 6, 12, 23 and 36 months after IPO, respectively. BAHR3, BAHR6, BAHR12, BAHR24 and BAHR36 represent the buy and hold returns for 3, 6, 12, 23 and 36 months after IPO, respectively. T-values are reported in brackets. The results for post-IPO performance of firms with and without $\mathrm{PE}$ are not reported here to save space because, like the reported results, these are insignificant.

\begin{tabular}{lrrrrr}
\hline & CAR3 & CAR6 & CAR12 & CAR24 & $\begin{array}{r}\text { CAR36 } \\
\text { Mean (\%) }\end{array}$ \\
Mean (\%) & Mean (\%) & Mean (\%) & Mean (\%) \\
NPCSPON & -3.35 & -1.71 & -2.75 & 2.72 & 28.33 \\
PCSPON & -4.93 & -3.86 & -4.53 & 3.26 & 27.84 \\
Diff. & $-1.58(0.31)$ & $-2.15(0.34)$ & $-1.78(0.54)$ & $0.54(0.91)$ & $-0.49(0.96)$ \\
& BAHR3 & BAHR6 & BAHR12 & BAHR24 & BAHR36 \\
& Mean (\%) & Mean (\%) & Mean (\%) & Mean (\%) & Mean (\%) \\
NPCSPON & -3.64 & -3.21 & -6.39 & 4.05 & 23.43 \\
PCSPON & -5.22 & -5.67 & -9.06 & 1.56 & 19.21 \\
Diff. & $-1.58(0.31)$ & $-2.48(0.34)$ & $-2.67(0.46)$ & $-2.48(0.63)$ & $-4.22(0.77)$ \\
\hline
\end{tabular}

Panel E. IPO approval of firms with and without political capital from 2004 to 2005.

\begin{tabular}{lrrrc}
\hline & Obs. & Mean $(\%)$ & Diff (\%) & P-value \\
\hline NPCCEO & 23 & 52.17 & \multirow{2}{*}{33.12} & \multirow{2}{*}{$0.00^{* * *}$} \\
PCCEO & 34 & 85.29 & & \\
\hline
\end{tabular}

\section{Empirical analysis}

\subsection{Regression models}

To examine the effect of political connections on the probability of IPO approval/post-IPO performance, the following equation is used in this study as a baseline regression model.

APPROVAL/Post-IPO performance $=\alpha+\beta_{1} \mathrm{PC}+\beta_{2}$ control variable

+ Industry, Year and listed board dummies $+\varepsilon$

Equation (1)

In equation (1), the dependent variables are either the APPROVAL dummy variable or post-IPO performance. When the APPROVAL dummy is used as a dependent variable, the model becomes a logistic model. Key independent variable PC is a proxy for political capital, which can be PCCEO, 
PCSPON and PE as respectively defined. All variables are defined in Appendix A. To control for the effect due to industry, year of application and listed board, we include several dummy variables in all of the regressions as proxies for these effects.

\subsection{The value of politically connected executives}

Our empirical analysis begins by investigating the value of politically connected executives, which is the major type of political capital in both IPO approval and post-IPO performance. We first estimate the impact of a politically connected executive (PCCEO) on IPO approval and then estimate its effect on post-IPO performance. The results are reported in Tables 3 and 4.

\subsubsection{The effect of a politically connected executive on IPO approval}

As per our expectations, the empirical results presented in Table 3 show that the IPO applications of entrepreneurial firms with a politically connected executive are more likely to be approved by the CSRC, demonstrating coefficients that are consistently and statistically significant. This result suggests that a politically connected executive does create value in the IPO approval process, which confirms our hypothesis H1. In addition, our results indicate that a politically connected executive in state-controlled firms has no significant impact on IPO approval, which is also consistent with our expectations. Our results indicate that Chinese entrepreneurial firms usually hire a politically connected executive as political capital to seek rent from the government, but the value of such connections is diluted by both state control and governmental objectives in state-controlled firms.

With respect to the control variables, we find that larger firms and firms with a higher ROE are more likely to obtain approval, which is consistent with the results of Shu et al. (2007), probably because these firms usually have lower information asymmetry and a better corporate governance system, whereas higher-leveraged firms and firms with a higher current ratio are less likely to gain IPO approval. These results indicate that as the first gatekeeper for investors, the regulator in China is concerned with both the profitability of pre-IPO firms and the risk of default.

Earnings management may be another important factor that has an impact on IPO approval: previous literature indicates that earnings management is widely adopted by prospective firms to obtain higher offering proceeds and initial firm value. For example, Teoh et al. (1998) and DuCharme et al. (2001) show that pre-IPO firms usually report earnings in excess cash flows by taking positive discretionary accruals. However, in Table 3, we do not find any significant relationship between earnings management and IPO approval, which confirms the results of a recent study by Chen et al. (2011).

Table 3

Effect of executives' political connections on IPO approval. This table presents the results of regression on the effect of executive's political connections on IPO approval of entrepreneurial firms (ENTRE) and state-controlled firms (STATE). Column 1 presents the results for entrepreneurial firms and column 2 presents the results for state-controlled firms. The dependent variable is the APPROVAL dummy. PSATATE is a control variable for entrepreneurial firms only. Definitions of all independent variables are reported in Appendix A. P-values are displayed in brackets. ${ }^{*}, * *$ and $* * *$ indicate significance at the $10 \%, 5 \%$ and $1 \%$ levels, respectively.

\begin{tabular}{lcc}
\hline Var. & & APPROVAL \\
PCCEO & ENTRE & STATE \\
& $0.53^{* *}$ & -0.37 \\
REPUTATION & $(0.02)$ & $(0.48)$ \\
& 0.23 & 0.00 \\
SIZE & $(0.73)$ & $(0.99)$ \\
& $0.54^{* * *}$ & $1.25^{* * *}$ \\
ROE & $(0.01)$ & $(0.01)$ \\
& $0.03^{* *}$ & 0.01 \\
\hline
\end{tabular}




\begin{tabular}{lcc}
\hline LEVERAGE & $-0.02^{* *}$ & $-0.06^{* *}$ \\
EM & $(0.05)$ & $(0.02)$ \\
& 0.32 & -3.44 \\
CURRENT & $(0.50)$ & $(0.45)$ \\
& -0.18 & -0.29 \\
OP- RISK & $(0.12)$ & $(0.59)$ \\
& -0.04 & -0.16 \\
PSTATE & $(0.48)$ & $(0.13)$ \\
& 0.00 & \\
Const & $(0.98)$ & $-20.05^{* *}$ \\
& $-8.61^{* *}$ & $(0.03)$ \\
Year & $(0.03)$ & Included \\
Industry & Included & Included \\
List board & Included & Included \\
$N$ & Included & 157 \\
pseudo $R^{2}$ & 749 & 0.180 \\
\hline
\end{tabular}

\subsubsection{The effect of a politically connected executive on post-IPO performance}

Table 4 presents the results of the regression regarding the impact of politically connected executives on post-IPO performance. Not surprisingly, executives' political connections are positively associated with firms' post-IPO performance measured by either CARs or BAHRs, and most of the regression coefficients are statistically and economically significant. This result indicates that minority shareholders do expect that a politically connected executive continues to create value for entrepreneurial firms after the IPO, which confirms our hypothesis H2.

Table 4

Effect of executives' political connections on post-IPO performance. This table presents the results of regression on the effect of executives' political connections on post-IPO performance. The dependent variable is post-IPO performance, measured by both CARs and BAHRs. The definitions of all independent variables are reported in Appendix A. Panels A and B present the results using CARs and BAHRs as dependent variables, respectively. P-values are displayed in brackets. ${ }^{*},{ }^{* *}$ and ${ }^{* * *}$ indicate significance at the $10 \%, 5 \%$ and $1 \%$ levels, respectively.

Panel A. CARs as a measure of post-IPO performance.

\begin{tabular}{lccccc}
\hline \multirow{2}{*}{ PCCEO } & CAR3 & CAR6 & CAR12 & CAR24 & CAR36 \\
\multirow{2}{*}{ LARGEST } & $0.03^{*}$ & $0.04^{*}$ & $0.05^{*}$ & $0.08^{*}$ & $0.14^{*}$ \\
& $(0.07)$ & $(0.07)$ & $(0.06)$ & $(0.06)$ & $(0.08)$ \\
SIZE & -0.00 & $-0.00^{* *}$ & -0.00 & -0.00 & -0.00 \\
& $(0.12)$ & $(0.02)$ & $(0.52)$ & $(0.61)$ & $(0.25)$ \\
ROE & -0.02 & -0.01 & $-0.05^{*}$ & $-0.15^{* * *}$ & $-0.21^{* * *}$ \\
& $(0.10)$ & $(0.54)$ & $(0.06)$ & $(0.00)$ & $(0.00)$ \\
LEVERAGE & 0.00 & 0.00 & 0.00 & -0.00 & -0.01 \\
& $(0.12)$ & $(0.17)$ & $(0.35)$ & $(0.24)$ & $(0.20)$ \\
P/E RATIO & 0.00 & -0.00 & -0.00 & 0.00 & -0.00 \\
& $(0.67)$ & $(0.58)$ & $(0.81)$ & $(0.64)$ & $(0.78)$ \\
Const & -0.00 & -0.00 & 0.00 & -0.00 & -0.01 \\
& $(0.81)$ & $(0.51)$ & $(0.86)$ & $(0.71)$ & $(0.52)$ \\
& 0.26 & -0.20 & 0.20 & $3.23^{* * *}$ & $4.78^{* * *}$ \\
\hline
\end{tabular}




\begin{tabular}{|c|c|c|c|c|c|}
\hline Year & Included & Included & Included & Included & Included \\
\hline Industry & Included & Included & Included & Included & Included \\
\hline List board & Included & Included & Included & Included & Included \\
\hline$N$ & 611 & 611 & 611 & 424 & 167 \\
\hline adj. $R^{2}$ & 0.078 & 0.166 & 0.185 & 0.213 & 0.313 \\
\hline 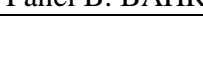 & BAHR3 & BAHR6 & BAHR12 & BAHR24 & BAHR36 \\
\hline \multirow[t]{2}{*}{ PCCEO } & $0.03^{*}$ & $0.04^{*}$ & $0.05^{*}$ & 0.06 & 0.16 \\
\hline & $(0.10)$ & $(0.07)$ & $(0.10)$ & $(0.20)$ & $(0.20)$ \\
\hline \multirow[t]{2}{*}{ LARGEST } & $-0.00 *$ & $-0.00 * *$ & -0.00 & -0.00 & -0.00 \\
\hline & (0.09) & $(0.02)$ & $(0.65)$ & (0.99) & (0.59) \\
\hline \multirow[t]{2}{*}{ SIZE } & -0.02 & -0.01 & -0.04 & $-0.12^{* * *}$ & $-0.26 * *$ \\
\hline & (0.19) & $(0.60)$ & $(0.13)$ & $(0.01)$ & $(0.03)$ \\
\hline \multirow[t]{2}{*}{ ROE } & 0.00 & 0.00 & 0.00 & -0.00 & -0.01 \\
\hline & $(0.12)$ & $(0.33)$ & $(0.40)$ & $(0.58)$ & $(0.41)$ \\
\hline \multirow[t]{2}{*}{ LEVERAGE } & -0.00 & -0.00 & 0.00 & 0.00 & 0.00 \\
\hline & $(0.98)$ & $(0.46)$ & $(0.81)$ & $(0.74)$ & (0.97) \\
\hline \multirow[t]{2}{*}{ P/E RATIO } & -0.00 & -0.00 & -0.00 & -0.00 & -0.02 \\
\hline & $(0.94)$ & $(0.56)$ & $(0.92)$ & $(0.68)$ & $(0.38)$ \\
\hline Year & Included & Included & Included & Included & Included \\
\hline Industry & Included & Included & Included & Included & Included \\
\hline List board & Included & Included & Included & Included & Included \\
\hline \multirow[t]{2}{*}{ Const } & 0.21 & -0.45 & -0.53 & $2.48^{* * *}$ & $5.74^{* *}$ \\
\hline & $(0.50)$ & $(0.35)$ & (0.39) & $(0.01)$ & $(0.04)$ \\
\hline$N$ & 611 & 611 & 611 & 424 & 167 \\
\hline $\operatorname{adj} . R^{2}$ & 0.091 & 0.225 & 0.347 & 0.180 & 0.255 \\
\hline
\end{tabular}

Overall, our results presented in Table 4 are consistent with the results of Liu et al. (2012), who find that politically connected firms outperform non-connected ones using a pooled sample of Chinese IPOs. However, as discussed above, Fan et al. (2007) find that Chinese state-controlled firms with political connections actually have poorer post-IPO performance. Therefore, we conduct a further regression using our sample of state-controlled firms, and our results confirm the negative relationship between political connections and post-IPO performance of Chinese state-controlled firms ${ }^{19}$.

\subsection{The effect of other political capital on IPO approval and post-IPO performance}

In this sub-section we examine political capital from other connections, including politically connected sponsors and PE investors. Our aim is to shed light on whether these types of political capital also contribute to firms' access to the IPO market, whether the effect of these connections is complementary to or a substitute for executives' connections and whether minority shareholders endorse the value of other types of political capital. The results are reported in Tables 5, 6 and 7.

The results in Table 5 show that politically connected sponsors and the presence of PE both have statistically positive effects on IPO approval. These results indicate that these types of political capital also bring benefits to the connected firms when accessing the IPO market, which is consistent with our hypothesis HЗa.

19 The results for state-controlled firms are not reported to save space. 
Table 5

Effect of other types of political capital on IPO approval. This table presents the results of regression on the effect of politically connected sponsors and PE on IPO approval of entrepreneurial firms. Columns 1 and 3 present the results without control for financial data; columns 2 and 4 present the results with control for financial data. Two observations are eliminated when we include financial variables in our model because these two firms' financial data are unavailable. The dependent variable is the APPROVAL dummy. Definitions of all independent variables are reported in Appendix A. The variable REPUTATION is omitted in columns 1 and 2 regarding the effect of politically connected sponsor on IPO approval. P-values are displayed in brackets. *, ** and *** indicate significance at the $10 \%, 5 \%$ and $1 \%$ levels, respectively.

\begin{tabular}{|c|c|c|c|c|}
\hline Var. & & & & \\
\hline PCSPON & $\begin{array}{l}0.39 * \\
(0.06)\end{array}$ & $\begin{array}{c}0.43^{* *} \\
(0.05)\end{array}$ & & \\
\hline $\mathrm{PE}$ & & & $\begin{array}{c}0.30 \\
(0.15)\end{array}$ & $\begin{array}{c}0.44^{* *} \\
(0.05)\end{array}$ \\
\hline REPUTATION & & & $\begin{array}{l}-0.02 \\
(0.98)\end{array}$ & $\begin{array}{c}0.11 \\
(0.87)\end{array}$ \\
\hline SIZE & & $\begin{array}{c}0.61^{* * *} \\
(0.00)\end{array}$ & & $\begin{array}{c}0.60^{* * *} \\
(0.00)\end{array}$ \\
\hline ROE & & $\begin{array}{l}0.02 * \\
(0.06)\end{array}$ & & $\begin{array}{l}0.02 * \\
(0.06)\end{array}$ \\
\hline LEVERAGE & & $\begin{array}{c}-0.02^{* *} \\
(0.04)\end{array}$ & & $\begin{array}{c}-0.02 * * \\
(0.04)\end{array}$ \\
\hline EM & & $\begin{array}{c}0.38 \\
(0.42)\end{array}$ & & $\begin{array}{c}0.33 \\
(0.46)\end{array}$ \\
\hline CURRENT & & $\begin{array}{l}-0.17 \\
(0.14)\end{array}$ & & $\begin{array}{l}-0.18 \\
(0.12)\end{array}$ \\
\hline OP-RISK & & $\begin{array}{l}-0.05 \\
(0.36)\end{array}$ & & $\begin{array}{l}-0.04 \\
(0.51)\end{array}$ \\
\hline PSTATE & & $\begin{array}{l}-0.00 \\
(0.88)\end{array}$ & & $\begin{array}{l}-0.01 \\
(0.57)\end{array}$ \\
\hline Const & $\begin{array}{c}-1.57^{* *} \\
(0.03)\end{array}$ & $\begin{array}{c}-13.16^{* * *} \\
(0.00)\end{array}$ & $\begin{array}{c}1.64 \\
(0.16)\end{array}$ & $\begin{array}{c}-9.73^{* *} \\
(0.01)\end{array}$ \\
\hline Year & Included & Included & Included & Included \\
\hline Industry & Included & Included & Included & Included \\
\hline List board & Included & Included & Included & Included \\
\hline$N$ & 751 & 749 & 751 & 749 \\
\hline pseudo $R^{2}$ & 0.103 & 0.126 & 0.101 & 0.126 \\
\hline
\end{tabular}

Table 6 shows that politically connected sponsors and the existence of PE have significantly positive effects on IPO approval in firms without politically connected executives, and their positive effect on IPO approval disappears in firms with politically connected executives; thus, our hypothesis H3b is also confirmed. The results indicate that politically connected executives and other political connections have a substitutionary effect on IPO approval.

Table 6

Effect of other types of political capital on IPO approval of firms with and without politically connected executives. This table presents the results of regression on the effect of political connections on IPO approval of firms with and without politically connected executives. PCCEO refers to firms with politically connected executives. NPCCEO refers to firms without politically connected executives. The dependent variable is the APPROVAL dummy. Definitions of all independent variables are reported 
in Appendix A. Columns 1 and 2 (columns 3 and 4) present the effect of politically connected sponsor (PE) on IPO approval of firms with and without politically connected executives. The variable REPUTATION is omitted in some regressions. P-values are displayed in brackets. *,** and *** indicate significance at the $10 \%, 5 \%$ and $1 \%$ levels, respectively.

\begin{tabular}{|c|c|c|c|c|}
\hline \multirow[t]{2}{*}{ Var. } & \multicolumn{4}{|c|}{ APPROVAL } \\
\hline & NPCCEO & PCCEO & NPCCEO & PCCEO \\
\hline \multirow[t]{2}{*}{ PCSPON } & $0.47 *$ & 0.28 & & \\
\hline & (0.09) & $(0.44)$ & & \\
\hline \multirow[t]{2}{*}{ PE } & & & $0.53^{*}$ & 0.46 \\
\hline & & & $(0.08)$ & $(0.25)$ \\
\hline \multirow[t]{2}{*}{ REPUTATION } & & & -0.81 & \\
\hline & & & $(0.31)$ & \\
\hline \multirow[t]{2}{*}{ SIZE } & $0.68^{* * *}$ & 0.47 & $0.67 * * *$ & 0.48 \\
\hline & $(0.01)$ & $(0.17)$ & $(0.01)$ & $(0.17)$ \\
\hline \multirow[t]{2}{*}{ ROE } & 0.02 & $0.04 *$ & 0.02 & $0.04 *$ \\
\hline & $(0.27)$ & $(0.07)$ & $(0.27)$ & $(0.06)$ \\
\hline \multirow[t]{2}{*}{ LEVERAGE } & -0.02 & -0.02 & -0.02 & -0.03 \\
\hline & $(0.18)$ & $(0.23)$ & $(0.13)$ & $(0.18)$ \\
\hline \multirow[t]{2}{*}{ EM } & -0.17 & 0.93 & -0.51 & 0.94 \\
\hline & $(0.89)$ & $(0.25)$ & (0.69) & $(0.12)$ \\
\hline \multirow[t]{2}{*}{ CURRENT } & -0.06 & -0.29 & -0.07 & $-0.36^{*}$ \\
\hline & $(0.74)$ & $(0.10)$ & $(0.68)$ & $(0.10)$ \\
\hline \multirow[t]{2}{*}{ OP-RISK } & 0.05 & $-0.16^{*}$ & 0.07 & $-0.17 *$ \\
\hline & $(0.64)$ & $(0.08)$ & $(0.53)$ & $(0.10)$ \\
\hline \multirow[t]{2}{*}{ PSTATE } & -0.00 & -0.00 & -0.01 & -0.01 \\
\hline & $(0.89)$ & $(0.97)$ & (0.59) & $(0.82)$ \\
\hline \multirow[t]{2}{*}{ Const } & $-15.61 * * *$ & -8.49 & $-14.85^{* * *}$ & -8.93 \\
\hline & $(0.00)$ & $(0.22)$ & $(0.00)$ & $(0.21)$ \\
\hline Year & Included & Included & Included & Included \\
\hline Industry & Included & Included & Included & Included \\
\hline List board & Included & Included & Included & Included \\
\hline$N$ & 410 & 329 & 410 & 317 \\
\hline pseudo $R^{2}$ & 0.160 & 0.090 & 0.163 & 0.103 \\
\hline
\end{tabular}

The results in Table 7 show that firms with politically connected sponsors and PE underperform compared to firms without but are statistically insignificant ${ }^{20}$, indicating that other types of political capital do not have significant effects on post-IPO performance. These results indicate that although other types of political capital do create value in the IPO approval process, their value disappears in the secondary market. Our results suggest that both politically connected sponsors and PE investors are less likely to play a better monitoring role in the post-IPO period than firms without this political capital.

Table 7

Effect of other types of political capital on post-IPO performance. This table presents the results of regression on the effect of politically connected sponsors and PE on post-IPO performance. Panels A and B present the results using CARs and BAHRs as

\footnotetext{
${ }^{20}$ These results are somewhat consistent with those of Chen et al. (2011), who find a negative relationship between a politically connected sponsor and post-IPO performance using a pooled sample of all listed firms, including both state-controlled and entrepreneurial firms.
} 
dependent variables, respectively. Control variables are included in our regressions, but the results are not reported to save space. P-values are displayed in brackets. *, ** and *** indicate significance at the $10 \%, 5 \%$ and $1 \%$ levels, respectively.

Panel A: CARs as measure of post-IPO performance.

\begin{tabular}{lccccc}
\hline \multirow{2}{*}{ PE } & CAR3 & CAR6 & CAR12 & CAR24 & CAR36 \\
& -2.59 & -1.59 & $-4.77^{*}$ & -1.86 & -1.86 \\
PCSPON & $(0.11)$ & $(0.47)$ & $(0.09)$ & $(0.69)$ & $(0.69)$ \\
& -1.33 & -1.68 & -0.81 & 1.01 & -5.33 \\
& $(0.38)$ & $(0.42)$ & $(0.76)$ & $(0.81)$ & $(0.51)$ \\
\hline$N$ & 611 & 611 & 611 & 424 & 167 \\
\hline \multicolumn{7}{r}{ Panel B: BAHRs as measure of post-IPO performance. } & & & \\
\hline \multirow{2}{*}{ PE } & BAHR3 & BAHR6 & BAHR12 & BAHR24 & BAHR36 \\
& $-2.84^{*}$ & -2.02 & -4.35 & -3.19 & -3.19 \\
PCSPON & $(0.09)$ & $(0.42)$ & $(0.11)$ & $(0.53)$ & $(0.53)$ \\
& -1.40 & -1.63 & -0.52 & -2.12 & -6.31 \\
& $(0.36)$ & $(0.48)$ & $(0.86)$ & $(0.65)$ & $(0.63)$ \\
\hline
\end{tabular}

\subsection{Addressing the issue of endogeneity}

Endogeneity may exist in our research because IPO approval, post-IPO performance and firms' political capital may be jointly affected by other, unobserved variables. This study addresses the potential endogeneity issue using the following methods: (1) a natural experiment; (2) a Heckman two-step analysis with instrumental variables; and (3) using the founder's political connection as a proxy for political capital that is less likely to be influenced by un-observables.

\subsubsection{Addressing the endogeneity issue using a natural experiment}

The best way to resolve potential endogeneity is to use an exogenous shock as a natural experiment (Rosenzweig and Wolpin, 2000). This study chose the economic stimulus package implemented by the Chinese government in November 2008 as an exogenous shock for two reasons. (1) As part of the stimulus package, the government put forward a series of policies to encourage entrepreneurial firms to go public in the market, and given that the CSRC's regulatory policy is greatly influenced by the Chinese central government, it is expected that the CSRC would approve more entrepreneurial firms' applications even if they do not have political capital. Therefore, we expect that the value of political capital is weakened after the implementation of the stimulus package. (2) The policy is an exogenous event that does not affect firms' political capital.

Based on our discussion above, we conduct a series of regressions to investigate whether the positive relationship between political capital and IPO approval is weakened after the implementation of the stimulus package. As shown in Table 8, the interaction of PCCEO and STIMULUS is significantly negatively associated with the probability of IPO approval, indicating that the value of politically connected executives in the IPO approval market is significantly reduced after the stimulus package. We also show that the positive effect of other types of political capital on IPO approval is also weakened after the stimulus package, but its effect is insignificant.

\section{Table 8}

Effect of political capital and the stimulus package on IPO approval. This table presents interaction effect of political capital (both executives' connections and other connections) and the stimulus package on IPO approval. STIMULUS is a dummy variable that equals 1 if the IPO application is submitted after November 9, 2008 when the government announced the stimulus package. The variable REPUTATION was omitted when running the regression. P-values are displayed in brackets. *, ** and $* * *$ indicate significance at the $10 \%, 5 \%$ and $1 \%$ levels, respectively.

\begin{tabular}{ll}
\hline Var. & APPROVAL \\
\hline
\end{tabular}




\begin{tabular}{|c|c|c|c|}
\hline STIMULUS & $\begin{array}{c}0.78^{* * *} \\
(0.01)\end{array}$ & $\begin{array}{c}0.18 \\
(0.58)\end{array}$ & $\begin{array}{c}0.26 \\
(0.41)\end{array}$ \\
\hline PCCEO & $\begin{array}{c}1.07^{* * *} \\
(0.01)\end{array}$ & & \\
\hline PCCEO*STIMULUS & $\begin{array}{c}-0.84^{*} \\
(0.08)\end{array}$ & & \\
\hline PCSPON & & $\begin{array}{c}0.40 \\
(0.25)\end{array}$ & \\
\hline PCSPON *STIMULUS & & $\begin{array}{l}-0.05 \\
(0.91)\end{array}$ & \\
\hline $\mathrm{PE}$ & & & $\begin{array}{c}0.77 * * \\
(0.04)\end{array}$ \\
\hline PE *STIMULUS & & & $\begin{array}{l}-0.46 \\
(0.31)\end{array}$ \\
\hline SIZE & $\begin{array}{c}0.56^{* * *} \\
(0.00)\end{array}$ & $\begin{array}{c}0.60 * * * \\
(0.00)\end{array}$ & $\begin{array}{c}0.58^{* * *} \\
(0.00)\end{array}$ \\
\hline ROE & $\begin{array}{c}0.02^{* *} \\
(0.04)\end{array}$ & $\begin{array}{l}0.02 * \\
(0.05)\end{array}$ & $\begin{array}{l}0.02 * \\
(0.06)\end{array}$ \\
\hline LEVERAGE & $\begin{array}{l}-0.02 * \\
(0.05)\end{array}$ & $\begin{array}{c}-0.02 * * \\
(0.05)\end{array}$ & $\begin{array}{c}-0.02 * * \\
(0.03)\end{array}$ \\
\hline EM & $\begin{array}{c}0.33 \\
(0.50)\end{array}$ & $\begin{array}{c}0.36 \\
(0.47)\end{array}$ & $\begin{array}{c}0.30 \\
(0.52)\end{array}$ \\
\hline CURRENT & $\begin{array}{l}-0.17 \\
(0.14)\end{array}$ & $\begin{array}{l}-0.18 \\
(0.13)\end{array}$ & $\begin{array}{l}-0.19 \\
(0.10)\end{array}$ \\
\hline OP-RISK & $\begin{array}{l}-0.04 \\
(0.50)\end{array}$ & $\begin{array}{l}-0.05 \\
(0.43)\end{array}$ & $\begin{array}{l}-0.03 \\
(0.60)\end{array}$ \\
\hline PSTATE & $\begin{array}{c}0.00 \\
(0.92)\end{array}$ & $\begin{array}{l}-0.00 \\
(0.90)\end{array}$ & $\begin{array}{l}-0.01 \\
(0.49)\end{array}$ \\
\hline Const & $\begin{array}{c}-9.12 * * \\
(0.02)\end{array}$ & $\begin{array}{c}-9.73^{* *} \\
(0.01)\end{array}$ & $\begin{array}{c}-9.44^{* *} \\
(0.02)\end{array}$ \\
\hline Year & Included & Included & Included \\
\hline Industry & Included & Included & Included \\
\hline $\begin{array}{l}\text { Listed board } \\
N\end{array}$ & $\begin{array}{c}\text { Included } \\
749\end{array}$ & $\begin{array}{c}\text { Included } \\
749\end{array}$ & $\begin{array}{c}\text { Included } \\
749\end{array}$ \\
\hline pseudo $R^{2}$ & 0.133 & 0.124 & 0.128 \\
\hline
\end{tabular}

\subsubsection{Heckman two-step estimation using IVs}

This study further conducts a Heckman two-step estimation to address the endogeneity of both politically connected executives and other types of political capital. The key to this method is that we choose instrument variables (IVs) that affect firms' political capital but are not related to our dependent variables; the best way to carry out this method is to find IVs that are exogenously determined and cannot be influenced by firm-specific factors. Because this study includes three key independent variables as proxies for political capital, we may use different IVs to estimate the likelihood of firms having different types of political capital. We choose the government intervention development index (GIID) of Chinese 
provinces provided by Fan et al. (2009) as an instrumental variable for executives' political connections. This index has been widely used as an instrumental variable in the literature (Chen et al., 2011). The GIID index is a score measuring the level of market development that is inversely related to government intervention activities, such that a higher GIID indicates less government intervention (or, more accurately, a freer market). Entrepreneurial firms in provinces with more government intervention (lower GIID) are more likely to have political connections because they can seek more resources from the government. Therefore, we expect that there is a significant negative relationship between GIID and the dummy variable PCCEO. Because politically connected sponsors are normally large and are located in capital cities, we expect that firms in capital cities find it easier to seek politically connected sponsors. Thus, we construct a dummy variable, CAPITALC, that equals 1 if the firm is in a capital city and 0 otherwise as an IV for PCSPON. Similarly, PE investors in China are even more concentrated. Indeed, our data show that more than $90 \%$ of Chinese PE investors are located in four of China's largest cities: Beijing, Shanghai, Shenzhen and Guangzhou. Previous studies also indicate that PE in the US are mainly located in the states of Massachusetts, California and Texas, which has a great influence on the investors' investment behavior (Baker and Gompers, 1999). Therefore, we create a dummy variable, TOPLOCA, that equals 1 if a firm is located in one of these four largest cities and use it as an IV for the PE dummy.

We then conduct our two-step estimation using the IVs as described. In the first step of the regression, we estimate the likelihood of a firm having its political capital status using a logit regression model, where dummy variables for different political capital (PCCEO, PCSPON and PE) are used as dependent variables and both IVs and control variables as independent variables. We then examine how the value predicted for political capital obtained from the first step influences the probability of IPO approval and post-IPO performance in the second step. The results are reported in Tables 9 and 10.

Table 9 presents the two-step results of the effect of political capital on IPO approval. The results of the first-step regression show that firms in provinces with more government intervention (lower GIID scores) are more likely to have more executive political capital. We also show that firms in China's four largest cities (capital cities) are more likely to have other types of political capital, including PE (politically connected sponsors). More importantly, the second-step results show that the predicted values for political capital have a significantly positive effect on IPO approval even after we control for the endogeneity issue using IVs, which is consistent with our baseline regression results reported in Tables 3 and 5.

\section{Table 9}

Heckman two-step regression: effect of political capital on IPO approval. This table presents the results of a two-step regression on the effect of political connections on the IPO approval of a Chinese entrepreneur sample. GIID is the score of governmental intervention of Chinese provinces provided by Fan et al. (2009); a lower GIID score indicates that a province experiences greater government intervention. TOPLOCA is a dummy variable that equals 1 if the IPO firm is located in one of China's four biggest cities. CAPITALC is a dummy variable that equals 1 if the IPO firm is located in a Chinese capital city. $\mathrm{PCCEO} \wedge^{\wedge}, \mathrm{PE}^{\wedge}$ and $\mathrm{PCSPON}^{\wedge}$ are the estimated values from the first-step regressions. Columns 1 to 3 present the results of the first-step regression, where the dependent variable is the political capital dummy. Columns 4 to 6 present the second-stage regression results using the APPROVAL dummy as a dependent variable and the estimated political capital values from the first stage as the main explanatory variable. The definitions of other variables are reported in Appendix A. P-values are displayed in brackets. *, ** and $* * *$ indicate significance at the $10 \%, 5 \%$ and $1 \%$ levels, respectively.

\begin{tabular}{|c|c|c|c|}
\hline & & & Second Step \\
\hline Var. & PCCEO & PCSPON & APPROVAL \\
\hline
\end{tabular}

$\begin{array}{ll}\mathrm{PCCEO}^{\wedge} & 2.41^{* *}\end{array}$

$\mathrm{PE}^{\wedge}$

$2.35^{* *}$

$\mathrm{PCSPON}^{\wedge}$

$0.18^{*}$ 


\begin{tabular}{|c|c|c|c|c|c|c|}
\hline \multirow{3}{*}{ TOPLOCA } & $(0.01)$ & & & & & \\
\hline & & $0.38 *$ & & & & \\
\hline & & $(0.06)$ & & & & \\
\hline \multirow[t]{2}{*}{ CAPITALC } & & & $0.32 * *$ & & & \\
\hline & & & $(0.05)$ & & & \\
\hline \multirow[t]{2}{*}{ REPUTATION } & -0.14 & $0.93^{*}$ & $2.53^{* * *}$ & 0.44 & -0.01 & 0.41 \\
\hline & $(0.75)$ & $(0.06)$ & $(0.00)$ & $(0.50)$ & $(0.99)$ & $(0.53)$ \\
\hline \multirow{2}{*}{ SIZE } & $0.57^{* * *}$ & -0.03 & -0.06 & 0.22 & $0.56 * * *$ & $0.54^{* * *}$ \\
\hline & $(0.00)$ & $(0.81)$ & $(0.62)$ & $(0.34)$ & $(0.00)$ & $(0.00)$ \\
\hline \multirow{2}{*}{ ROE } & $-0.02 * * *$ & $-0.01^{*}$ & 0.01 & $0.03^{* * *}$ & $0.03 * *$ & $0.02 *$ \\
\hline & $(0.01)$ & $(0.08)$ & $(0.31)$ & $(0.01)$ & $(0.02)$ & $(0.07)$ \\
\hline \multirow[t]{2}{*}{ LEVERAGE } & -0.00 & 0.01 & 0.00 & $-0.02 * *$ & $-0.03^{* *}$ & $-0.02 * *$ \\
\hline & (0.69) & (0.19) & $(0.92)$ & $(0.03)$ & $(0.01)$ & $(0.03)$ \\
\hline \multirow[t]{2}{*}{ EM } & 0.53 & 0.13 & 0.32 & 0.09 & 0.19 & 0.21 \\
\hline & $(0.46)$ & $(0.64)$ & $(0.71)$ & $(0.84)$ & $(0.70)$ & $(0.66)$ \\
\hline \multirow[t]{2}{*}{ CURRENT } & 0.07 & 0.11 & 0.00 & $-0.28 * * *$ & $-0.32 * * *$ & $-0.29 * * *$ \\
\hline & $(0.51)$ & $(0.31)$ & $(0.96)$ & $(0.01)$ & $(0.00)$ & $(0.01)$ \\
\hline \multirow{2}{*}{ OP-RISK } & -0.00 & -0.06 & 0.08 & -0.01 & 0.02 & -0.01 \\
\hline & $(0.98)$ & $(0.20)$ & $(0.14)$ & $(0.83)$ & $(0.80)$ & $(0.91)$ \\
\hline \multirow[t]{2}{*}{ PSTATE } & 0.01 & $0.20^{* * *}$ & -0.01 & 0.01 & -0.04 & 0.01 \\
\hline & $(0.51)$ & $(0.00)$ & $(0.47)$ & $(0.51)$ & (0.19) & $(0.47)$ \\
\hline \multirow[t]{2}{*}{ Const } & $-10.03^{* * *}$ & -1.09 & 1.10 & -3.72 & $-10.79 * * *$ & $-9.41 * *$ \\
\hline & $(0.00)$ & $(0.70)$ & (0.67) & $(0.40)$ & $(0.00)$ & $(0.01)$ \\
\hline Year & Included & Included & Included & Included & Included & Included \\
\hline Industry & Included & Included & Included & Included & Included & Included \\
\hline Listed board & Included & Included & Included & Included & Included & Included \\
\hline $\mathrm{N}$ & 749 & 749 & 749 & 749 & 749 & 749 \\
\hline pseudo $R^{2}$ & 0.082 & 0.134 & 0.038 & 0.050 & 0.049 & 0.048 \\
\hline
\end{tabular}

In Table 10, we report the results of the second-step regression for the effect of politically connected executives on post-IPO performance. As predicted, we find that politically connected executives also have a consistently positive effect on post-IPO performance, which is consistent with our baseline regression results reported in Table 4. Our results are robust after controlling for the endogeneity issue. Overall, the Heckman two-step estimation confirms that our main results are robust.

Table 10

Heckman two-step regression: effect of political capital on post-IPO performance. This table presents the results of two-step regression on the effect of political connections on post-IPO performance of entrepreneur firms. PCCEO $\wedge$ represents the predicted value of politically connected executives. Panel A (B) reports the results obtained using CAR (BAHR) as measures of post-IPO performance. The definitions of other variables are reported in Appendix A. P-values are displayed in brackets. *, ** and $* * *$ indicate significance at the $10 \%, 5 \%$ and $1 \%$ levels, respectively.

Panel A. CARs as measure of post-IPO performance

\begin{tabular}{lccccc}
\hline & CAR3 & CAR6 & CAR12 & CAR24 & CAR36 \\
\hline PCCEO $^{\wedge}$ & 1.18 & $1.68^{*}$ & $2.20^{*}$ & $3.77^{*}$ & $6.68^{*}$ \\
\multirow{2}{*}{ LARGEST } & $(0.12)$ & $(0.10)$ & $(0.10)$ & $(0.07)$ & $(0.08)$ \\
& -0.08 & $-0.17^{* *}$ & -0.06 & -0.07 & -0.34 \\
SIZE & $(0.13)$ & $(0.03)$ & $(0.54)$ & $(0.63)$ & $(0.26)$ \\
& -1.98 & -0.75 & -3.93 & $-13.66^{* * *}$ & $-19.66^{* * *}$
\end{tabular}




\begin{tabular}{|c|c|c|c|c|c|}
\hline & $(0.15)$ & $(0.70)$ & $(0.10)$ & $(0.00)$ & $(0.01)$ \\
\hline \multirow[t]{2}{*}{ ROE } & 0.11 & 0.12 & 0.10 & -0.30 & -0.69 \\
\hline & $(0.17)$ & $(0.24)$ & $(0.48)$ & $(0.16)$ & (0.15) \\
\hline \multirow[t]{2}{*}{ LEVERAGE } & 0.02 & -0.06 & -0.04 & 0.07 & -0.14 \\
\hline & $(0.72)$ & $(0.54)$ & $(0.76)$ & (0.69) & $(0.71)$ \\
\hline \multirow[t]{2}{*}{ P/E RATIO } & -0.01 & -0.05 & 0.01 & -0.07 & -0.71 \\
\hline & $(0.78)$ & $(0.49)$ & (0.89) & $(0.68)$ & $(0.52)$ \\
\hline \multirow[t]{2}{*}{ Const } & 11.61 & -32.61 & 10.51 & $268.20^{* * *}$ & $400.74^{* *}$ \\
\hline & $(0.68)$ & $(0.41)$ & $(0.83)$ & $(0.00)$ & $(0.02)$ \\
\hline Year & Included & Included & Included & Included & Included \\
\hline Industry & Included & Included & Included & Included & Included \\
\hline Listed board & Included & Included & Included & Included & Included \\
\hline$N$ & 611 & 611 & 611 & 424 & 167 \\
\hline $\operatorname{adj} . R^{2}$ & 0.076 & 0.165 & 0.184 & 0.212 & 0.312 \\
\hline \multicolumn{6}{|c|}{ Panel B: BAHRs as measure of post-IPO performance } \\
\hline & BAHR3 & BAHR6 & BAHR12 & BAHR24 & BAHR36 \\
\hline \multirow[t]{2}{*}{ РCCEO^ } & $1.09 *$ & $1.95^{*}$ & 2.12 & 2.82 & 7.80 \\
\hline & $(0.09)$ & $(0.09)$ & $(0.15)$ & $(0.23)$ & $(0.21)$ \\
\hline \multirow[t]{2}{*}{ LARGEST } & $-0.09 *$ & $-0.18^{* *}$ & -0.04 & 0.00 & -0.25 \\
\hline & $(0.09)$ & $(0.03)$ & $(0.68)$ & (0.99) & $(0.61)$ \\
\hline \multirow[t]{2}{*}{ SIZE } & -1.56 & -0.62 & -3.53 & $-10.83 * *$ & $-23.75 * *$ \\
\hline & $(0.26)$ & $(0.77)$ & $(0.19)$ & $(0.01)$ & $(0.05)$ \\
\hline \multirow[t]{2}{*}{ ROE } & 0.11 & 0.09 & 0.10 & -0.16 & -0.73 \\
\hline & $(0.16)$ & $(0.45)$ & $(0.51)$ & $(0.48)$ & $(0.34)$ \\
\hline \multirow[t]{2}{*}{ LEVERAGE } & -0.01 & -0.08 & 0.03 & 0.06 & -0.02 \\
\hline & $(0.94)$ & $(0.43)$ & $(0.85)$ & $(0.78)$ & $(0.98)$ \\
\hline \multirow[t]{2}{*}{ P/E RATIO } & -0.01 & -0.05 & -0.01 & -0.08 & -1.56 \\
\hline & $(0.92)$ & $(0.54)$ & (0.89) & $(0.67)$ & $(0.38)$ \\
\hline \multirow[t]{2}{*}{ Const } & 0.57 & -55.61 & -63.19 & $193.71 * *$ & 444.91* \\
\hline & $(0.98)$ & $(0.20)$ & $(0.26)$ & $(0.04)$ & $(0.10)$ \\
\hline Year & Included & Included & Included & Included & Included \\
\hline Industry & Included & Included & Included & Included & Included \\
\hline Listed board & Included & Included & Included & Included & Included \\
\hline$N$ & 611 & 611 & 611 & 424 & 167 \\
\hline $\operatorname{adj} . R^{2}$ & 0.090 & 0.225 & 0.346 & 0.179 & 0.254 \\
\hline
\end{tabular}

4.4.3. The effect of founders' political connections on IPO approval

Lastly, to address the endogeneity of politically connected executives, we use the founder's political connections as our new measure of politically connected executives. The founder's connections are defined by a firm having a politically connected founder when it was established, where that founder is also currently the firm's executive. This measure is expressed as a dummy variable, PCFD1. For robustness, we extend our definition to include any politically connected founder regardless of whether the founder is currently the executive and define another new variable, PCFD2. These two variables are exogenous because they cannot be influenced by other factors. The results are reported in Table 11 .

As shown in panel A of Table 11, we find that $40 \%$ of our sample firms have been established by politically connected founders, and the largest proportion (38\%) of these connected founders are currently 
executives of the firms. In addition, the results of the univariate test indicate that firms with politically connected founders have a significantly higher probability of IPO approval than firms without. The results in panel B show that both PCFD1 and PCFD2 are significantly positively associated with IPO approval, suggesting that a positive relationship between politically connected executives and IPO approval does exist in Chinese entrepreneurial firms, confirming the robustness of our hypothesis H1.

\section{Table 11}

Effect of founder's political connections on approval of IPO.

Panel A. Summary statistics and univariate test results for firms with and without politically connected founders. This panel presents the summary statistics for politically connected founders and the results of a univariate test for the IPO approval of firms with and without politically connected founders. PCFD1 and NPCFD1, respectively, refer to firms with and without a politically connected founder, where the founder is currently the firm's executive; PCFD2 and NPCFD2, respectively, refer to firms with and without politically connected founders, regardless of whether the founder is currently the executive. ${ }^{* *}$ and $* * *$ indicate significance at the $5 \%$ and $10 \%$ levels, respectively.

\begin{tabular}{lcrrrrr}
\hline Variable & Obs & Mean & Median & Std. Dev. & Min & Max \\
PCFD1 & 751 & 0.38 & 0.00 & 0.49 & 0.00 & 1.00 \\
PCFD2 & 751 & 0.40 & 0.00 & 0.49 & 0.00 & 1.00 \\
\hline & \multicolumn{1}{c}{ Obs. } & Mean (\%) & Diff (\%) & P-value \\
& NPCFD1 & 463 & 80.35 & 6.81 & $0.02^{* *}$ \\
& PCFD1 & 288 & 87.15 & & \\
& NPCFD2 & 450 & 80.00 & 7.38 & $0.01^{* * *}$ \\
& PCFD2 & 301 & 87.38 & & \\
\hline
\end{tabular}

Panel B. Effect of founders' political connections on IPO approval. This panel presents the results of regression on the effect of politically connected founders on IPO approval. The dependent variable is the APPROVAL dummy. The definitions of all independent variables are reported in Appendix A. P-values are displayed in brackets. $*$, ** and $* * *$ indicate significance at the $10 \%, 5 \%$ and $1 \%$ levels, respectively.

\begin{tabular}{|c|c|c|c|c|}
\hline 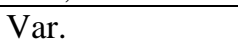 & & & & \\
\hline PCFD1 & $\begin{array}{c}0.44 * * \\
(0.05)\end{array}$ & $\begin{array}{l}0.38^{*} \\
(0.10)\end{array}$ & & \\
\hline PCFD2 & & & $\begin{array}{c}0.59 * * * \\
(0.01)\end{array}$ & $\begin{array}{c}0.54^{* *} \\
(0.02)\end{array}$ \\
\hline REPUTATION & $\begin{array}{c}0.10 \\
(0.87)\end{array}$ & $\begin{array}{c}0.28 \\
(0.67)\end{array}$ & $\begin{array}{c}0.06 \\
(0.92)\end{array}$ & $\begin{array}{c}0.23 \\
(0.73)\end{array}$ \\
\hline SIZE & & $\begin{array}{c}0.55^{* * *} \\
(0.00)\end{array}$ & & $\begin{array}{c}0.55^{* * *} \\
(0.01)\end{array}$ \\
\hline ROE & & $\begin{array}{c}0.02^{* *} \\
(0.04)\end{array}$ & & $\begin{array}{c}0.03^{* *} \\
(0.03)\end{array}$ \\
\hline LEVERAGE & & $\begin{array}{c}-0.02 * * \\
(0.05)\end{array}$ & & $\begin{array}{c}-0.02 * * \\
(0.05)\end{array}$ \\
\hline EM & & $\begin{array}{c}0.33 \\
(0.49)\end{array}$ & & $\begin{array}{c}0.32 \\
(0.50)\end{array}$ \\
\hline CURRENT & & $\begin{array}{c}-0.18 \\
(0.12)\end{array}$ & & $\begin{array}{l}-0.18 \\
(0.13)\end{array}$ \\
\hline OP-RISK & & $\begin{array}{l}-0.04 \\
(0.46)\end{array}$ & & $\begin{array}{l}-0.04 \\
(0.48)\end{array}$ \\
\hline PSTATE & & -0.00 & & 0.00 \\
\hline
\end{tabular}


$(0.98)$

$(0.94)$

\begin{tabular}{lcccc}
\hline Const & 1.57 & $-8.87^{* *}$ & 1.40 & $-8.92^{* *}$ \\
& $(0.18)$ & $(0.03)$ & $(0.23)$ & $(0.03)$ \\
Year & Included & Included & Included & Included \\
Industry & Included & Included & Included & Included \\
List board & Included & Included & Included & Included \\
$N$ & 751 & 749 & 751 & 749 \\
pseudo $R^{2}$ & 0.104 & 0.125 & 0.109 & 0.129 \\
\hline
\end{tabular}

\section{Conclusions}

This study examines the value of political capital in the IPO market using a recent sample of prospective Chinese IPO firms. We find that a politically connected executive facilitates firms' access to equity markets and that this political value in the IPO approval process exists in entrepreneurial firms rather than state-controlled firms. The results indicate that entrepreneurial firms seek rent from the government through their political capital of connected executives. Although state-controlled firms also have politically connected managers nominated by the government, their interests are mainly aligned with those of the government. We further document that politically connected entrepreneurial firms have better post-IPO performance than non-connected ones, indicating that the value of political connections is endorsed by minority shareholders in the post-IPO market.

In addition, our findings indicate that other types of political capital, including politically connected sponsors and PE, also bring benefit to firms when accessing the IPO market, but their value seems to be short lived, and disappears after the firms go public. Finally, we find that our results are robust when we apply different methods to alleviate the potential endogeneity problem.

Overall, our study extends the current literature on the value of political capital in emerging markets. For instance, previous literature indicates that political capital through politically connected executives provides connected firms with better access to financial resources in the private financial market. However, our findings provide direct evidence that in an emerging market, although the IPO market has become more market-oriented, an executive's political connection still creates value for entrepreneurial firms accessing the IPO market. In addition, the value of such political capital is endorsed by the market because shareholders believe such connections will continue to bring benefits to the connected firms after IPO. We also contribute to the current literature on political capital by finding that, in addition to politically connected executives, firms in an emerging market also seek political capital through external connections, such as a politically connected sponsors and PE, to facilitate their access to the IPO market, even though those connections do not create value after the firms go public. Overall, our findings confirm the value of political capital in emerging markets.

\section{Acknowledgments}

The authors are grateful to the valuable comments by an anonymous referee, the suggestions by Stuart L. Gillan and Jeffry Netter (the Editors). We acknowledge the valuable suggestions and comments on this paper by Lixin Colin Xu, Jing Shi, Henry Honghai Yu, Hongqi Yuan, Xiangkang Yin and other participants in seminars at the School of Finance, Shanghai Lixin University of Commerce, 28 September 2012, Hanqing Advanced Institute of Economics and Finance, Renmin University of China, 26 September 2012, Deliotte Fudan Accounting Forum, School of Accounting, Fudan University, 25 September 2012, School of Accounting Economics and Finance, Deakin University, 6 September 2012, Department of Finance, School of Business, La Trobe University, 2 March 2012; Department of Finance, Shanghai University of Finance and Economics, 10 April, 2012; School of Management \& Engineering, Nanjing University, 12 April, 2012,the 2013 China's International Conference in Finance, 10-13 July, 2013, Shanghai and the 2012 Asian Finance Association conference, 6-9 July, 2012, Taipei. 


\section{Appendix A. Detailed definition of variables}

\begin{tabular}{|c|c|}
\hline Variables & Definition \\
\hline \multicolumn{2}{|l|}{ Dependent variables } \\
\hline APPROVAL & $\begin{array}{l}\text { A dummy variable that equals } 1 \text { if the IPO application is approved } \\
\text { and } 0 \text { otherwise. }\end{array}$ \\
\hline CARs & $\begin{array}{l}\text { Post-IPO cumulative abnormal returns for } 3,6,12,24 \text { and } 36 \\
\text { months. }\end{array}$ \\
\hline BAHRs & Post-IPO buy-and-hold returns for 3, 6, 12, 24 and 36 months. \\
\hline \multicolumn{2}{|l|}{ Independent variables } \\
\hline & $\begin{array}{l}\text { A dummy variable that equals } 1 \text { if the executive is currently or } \\
\text { was formerly an officer of the government or military or a deputy }\end{array}$ \\
\hline PCCEO & $\begin{array}{l}\text { of the People's Congress or People's Political Consultative } \\
\text { Conference. }\end{array}$ \\
\hline PCSPON & $\begin{array}{l}\text { A dummy variable that equals } 1 \text { if the sponsor of the firm is } \\
\text { politically connected. }\end{array}$ \\
\hline $\mathrm{PE}$ & $\begin{array}{l}\text { A dummy variable that equals } 1 \text { if the firm has PE/VC investors as } \\
\text { one of the top } 2 \text { to } 10 \text { shareholders. }\end{array}$ \\
\hline PCFD1 & $\begin{array}{l}\text { A dummy variable that equals } 1 \text { if the firm has politically } \\
\text { connected founders. }\end{array}$ \\
\hline PCFD2 & $\begin{array}{l}\text { A dummy variable that equals } 1 \text { if the firm has politically } \\
\text { connected founders, and the founders are currently the firm's } \\
\text { executive. }\end{array}$ \\
\hline STIMULUS & $\begin{array}{l}\text { A dummy variable that equals } 1 \text { if the IPO application is } \\
\text { submitted after November 9, } 2008 \text { when the government } \\
\text { announced the stimulus package. }\end{array}$ \\
\hline REPUTATION & $\begin{array}{l}\text { A dummy that equals } 1 \text { if the firm's sponsor ranks in the top } 5 \\
\text { according to sponsor fees in the industry. }\end{array}$ \\
\hline SIZE & Natural logarithm of total assets. \\
\hline ROE & Ratio of earnings to total equity. \\
\hline CURRENT & Ratio of total current assets to total current liabilities. \\
\hline LEV & Ratio of total debt to total assets. \\
\hline EM & $\begin{array}{l}\text { The absolute value of discretionary accruals estimated from the } \\
\text { modified Jones model (Kothari et al., 2005). }\end{array}$ \\
\hline OP-RISK (operation risk) & Standard deviation of change in operation risk in the past 3 years. \\
\hline PSTATE & Percentage of state owned shares in entrepreneur controlled firms. \\
\hline LARGEST & Proportion of shares held by largest shareholders. \\
\hline P/E RATIO & Issue price divided by earnings per shares in the previous year. \\
\hline \multicolumn{2}{|l|}{ Instrument variables } \\
\hline GIID & $\begin{array}{l}\text { Score of government intervention index of Chinese provinces } \\
\text { provided by Fan et al. (2009). }\end{array}$ \\
\hline CAPITALC & $\begin{array}{l}\text { A dummy variable that equals } 1 \text { if the firm is located in a capital } \\
\text { city and } 0 \text { otherwise. }\end{array}$ \\
\hline TOPLOCA & $\begin{array}{l}\text { A dummy variable that equals } 1 \text { if a firm is located in one of the } \\
\text { four largest cities (Beijing, Shanghai, Guangzhou or Shenzhen) } \\
\text { and } 0 \text { otherwise. }\end{array}$ \\
\hline
\end{tabular}




\section{References}

Adhikari, A., Derashid, C. Zhang, H., 2006. Public policy, political connections, and effective tax rates: longitudinal evidence from Malaysia. Journal of Accounting and Public Policy, 25: 574-95.

Agrawal, A., Knoeber, C.K., 2001. Do some outside directors play a political role? Journal of Law and Economics, 44: 179-198.

Baker, M., Gompers, P., 1999. Executive ownership and control in newly public firms: the role of venture capitalists. SSRN working paper.

Berkman, H., Cole, R.A., Fu, L.J. 2010. Political connections and minority shareholder protection: evidence from securities market regulation in China. Journal of Financial and Quantitative Analysis, 45(6): 1391-1417.

Bruton, G. D., Ahlstrom, D., Singh, K. 2002. The impact of the institutional environment on the venture capital industry in Singapore. Venture Capital, 4(3): 197-218.

Chaney, P.K., Faccio, M., Parsley, D., 2011. The quality of accounting information in politically connected firms. Journal of Accounting and Economics, 51: 58-76.

Chen, D., Guan, Y., Zhang, T., Zhao, G., 2011. Political connection of financial intermediary: evidence from China's IPO market. City University of Hong Kong working paper.

Chen, C. J.P., Li, Z., Su, X., Sun, Z., 2011. Rent-seeking incentives, corporate political connections, and the control structure of private firms: Chinese evidence. Journal of Corporate Finance, 17: 229-243.

China Securities Regulatory Commission, Decree No. 30. 2006. The administrative measures for the issuance of securities by listed companies. May 6. [In Chinese].

China Securities Regulatory Commission, Decree No. 63. 2009. The new amendment measures for the administration of the sponsor business of securities issuance and listing. May 13 (In Chinese).

Claessens, S., Feijen, E., Laeven, L., 2008. Political connections and preferential access to finance: the role of campaign contributions. Journal of Financial Economics, 88: 554-580.

Cull, R., Xu, L., 2003. Who gets credit? The behaviour of bureaucrats and state banks in allocating credit to Chinese state-owned enterprises. Journal of Development Economics, 71(2): 533-559.

DuCharme, L.L., Malatesta, P.H., Sefcik, S.E. 2001. Earnings Management: IPO Valuation and Subsequent Performance. Journal of Accounting, Auditing and Finance, 16 (4), 369-396.

Engel, E., Gordon, E., Hayes, R., 2002. The role of performance measures and monitoring in annual governance decisions in entrepreneurial firms. Journal of Accounting Research, 40: 485-518.

Faccio, M., 2006. Politically connected firms. American Economic Review 96 (1): 369-386.

Faccio, M., Masulis, R., McConnell, J.J., 2006, Political connections and corporate bailouts, Journal of Finance, 61: 2597-2635.

Fan, G., Wang, X.L., Zhu, H.P., 2009. The Marketization Index of China: The Process of Regional Marketization Report 2007, Press of Economic Science, Beijing (in Chinese).

Fan, J., Wong, T.J., Zhang, T., 2007. Politically connected CEOs, corporate governance, and post-IPO performance of China's newly partially privatized firms. Journal of Financial Economics, 84: 330-357.

Fan, J., Wei, J., Xu, X., 2011. Corporate finance and governance in emerging markets: A selective review and an agenda for future research. Journal of Corporate Finance, 17: 207-214.

Firth, M., Lin, C., Liu, P., Wong, S.M.L., 2009. Inside the black box: Bank credit allocation in China's private sector. Journal of Banking \&Finance, 33(6): 1144-1155.

Firth, M., Peter, M.Y.F., Olive, M.R., 2006. Firm performance, governance structure, and top management turnover in a transitional economy. Journal of Management Studies, 43(6): 1289-1330.

Fisman, R., 2001. Estimating the value of political connections. American Economic Review, 91: 1095-1102.

Gompers, P., 1995. Optimal Investment, Monitoring, and the Staging of Venture Capital. Journal of Finance, 50: 1461-1490.

Hochberg, Y.V., 2008. Venture Capital and Corporate Governance in Newly Public Firms. SSRN Working paper. 
Johnson, S., Mitton, T., 2003, Cronyism and capital controls: evidence from Malaysia. Journal of Financial Economics, 67: 351-382.

Khwaja, A., Mian, A., 2005. Do lenders favor politically connected firms? Rent provision in an emerging financial market. Quarterly Journal of Economics, 120(4): 1371-1411.

Kothari, S.P., Leone, A.J., Wasley, C.E., 2005. Performance matched discretionary accrual measures. Journal of Accounting and Economics, 39, 163-197.

Krishnan, C.N.V., Ivanov, V.I., Masulis, R.W., Singh, A.K., 2011. Venture capital reputation, post-IPO performance and corporate governance. Journal of Financial and Quantitative Analysis, 46 (5), 1295-1333.

Li, H., Meng, L., Wang, Q., Zhou, L., 2008, Political connections, financing and firm performance: Evidence from Chinese private firms. Journal of Development Economics, 87: 283-299.

Li, H., Meng, L., Zhang, J., 2006. Why do entrepreneurs enter politics: Evidence from China. Economic Inquiry, 44 (3): 559-578.

Li, Z., Yang, C., 2003. Corporate performance, control transfer and management turnover: An empirical research based on China's securities markets. China Accounting and Finance Review, 5: 78-108.

Li, K., Yue, H., Zhao, L., 2009. Ownership, institutions, and capital structure: Evidence from China. Journal of Comparative Economics, 37 (3): 471-490.

Liu, J., Uchida, K., Gao, R., 2012, Political connections and the long-term stock performance of Chinese IPOs. Journal of International Financial Markets, Institutions \& Money, 22: 814-833.

Naqi, S. A., Hettihewa, S., 2007. Venture capital or private equity? Asian Experience Business Horizons, 50(4): 335-344.

Nee, V., Opper, S., 2013. Political capital in a market economy, Social Forces, Forthcoming.

Rosenzweig, M.R., Wolpin, K.I., 2000. Natural "Natural experiments" in economics. Journal of Economic Literature, 38: 827-874.

Ramalho, R., 2007. The Persistence of Corruption: Evidence from the 1992 Presidential Impeachment in Brazil, Working Paper, World Bank.

Roberts, B.E., 1990. A dead senator tells no lies: seniority and the distribution of federal benefits. American Journal of Political Science, 34: 31-58.

Shu, P.G., Yeh, Y.H., Su, Y.H., 2009. Decision of the IPO reviewing committee: cause and consequences. Emerging markets Finance and Trade, 45: 67-82.

Teoh, S.H., Welch, I., Wong, T.J. 1998. Earnings management and the long-run market performance of initial public offerings. The Journal of Finance, 6: 1935-1974.

Wu, J., Li, S., Li, Z., 2012. The contingent value of CEO political connections: A study on IPO performance in China. Asia Pacific Journal of Management, Forthcoming.

Yang, Z., 2013, Do political connections add value to audit firms, evidence from IPO audits in China, Contemporary Accounting Research, forthcoming. 